(C) Dr. Basanta Kumar Mohanta

\title{
6 Importance of Beles (Prickly-Pear Cactus) for the Eritrean Highlanders, Horn of Africa: An Analysis
}

Dr. Basanta Kumar Mohanta, Dr. Basanta Kumar Mohanta,Department of Sociology and Anthropology, College of Business and Social Sciences, Adi-Keih, Eritrea, North-East Africa. email:drmohantabk@gmail.com

\begin{abstract}
Beles- prickly pear cactus plant,known to human beingsince the time of Pleistocene era and was subsequently domesticated. It is a native plant of Mexico which is the known as the biggest cactus pear producer country of the world. The different parts of this cactus plant are used for different purposes throughout the globe. But in case of the North Eastern Africa in general and the highland of Eritrea in particular, it introduced very late where it is mainly used as animal fodder and raw human food. Besides, it also plays a significant role as household income and poverty alleviation in both the production and consumption areas. Since this present study area is located in sub-Saharan desert area and since, the beles plant is able to adapt different climatic conditions has allowed the plant to grow in many parts of Eritrea. Thus, the plant gaining new respect as a potential food source in an area which have inconsistent rainfall, environmental degradation, poor quality soils and other problems. Even if, its introduction to the highlanders of Eritrea is comparatively very recent, it occupies an important place in the economy and subsistence of these people. In this article an attempt has been made to discuss about the importance of beles for the people of highland Eritrea, Africa. Dataare collected both from the primary and secondary sources.
\end{abstract}

Key words: Beles, Cactus, Prickly, Pear, Food, Eritrea, Africa

\section{Introduction}

The prickly-pear cactus plant is native to South America (Mexico). It is commonly known as 'Beles' in Arabic. It is believedto have been introduced to the people of Mexico in long past and is the world's biggest cactus pear fruit producer, with 72,500 ha of fruit farms producing a variety of coloured fruit, like yellow, white, red andorange (Sáenz, Carmen. 2013:119).At the time of describing the origin history of this plant, Flannery (1985) mentioned that the prehistoric aboriginal group of the semi-arid basins and valleys of the statesof Guerrero, Hidalgo, Mexico, Morelos Oaxaca and Puebla started cultivating a series of native plants between the end of the Pleistocene (ca. 100,000 years B.P.) and the beginning of the fifth 


\section{(C) Dr. Basanta Kumar Mohanta}

millennium $\mathrm{AD}$, which gradually became the basic foodstuffs of the ancient American. The nomadic life of these Native American continued fora long period of timewhen they learnt about the technique of gathering as well as the use of different plants and plant products. The knowledge of roasting this pricklypear cactus plant and agave make them edible, and to extract syrup from the pods of the mesquiteknow to these groups during this time. Further, he suggests, perhaps this cactus(opuntias)and some other semitropical fruits arose between 7,500and 5,000 years BC.From the time whenhuman beingsarrived in the desert and semi-desert zones of man in Mexico, about 20,000 years ago,this cactus have been significant as a means of sustenance, it is potable and works as a medicine too. These ancient Mexicans were consuming it abundantly from the wild, long before the beginning of its cultivation (Anaya-Pérez 2002:5).This prickly-pear cactus plant is commonly planted as a hedge plant in India and naturalized in waste ground,is from the cactacea family (opuntia ficus indicia) and a fleshy bush and small tree. The term 'prickly pear' is derived from the plant's fruit, which is spiny and pear shaped.It is a sweet juicy fruit which is pealed and eaten by the local people during the rainy season. The plant may reach a height of 05 meter and prefers calcareous soil with in semi-arid climate, in a temperature ranging from 18-26c. It is propagated by vegetative means (cladodes or shoots).The cactus pears ability to adapt to different climatic environmentshas allowed the plant to be cultivated in many continents, such as Europe, America, Asia and Africa. It is generally accepted that the cactus plantations cover more than a million hectare all over the world. Apart from the Mexico, it is also found as an exotic plant in Algeria, Brazil, Chile, Eritrea, Ethiopia, India, Israel, Italy, Kenya, Libyan Arab Jamahiriya, Morocco, Portugal, South Africa, Spain, Sudan, Tanzania, Tunisia, Uganda, United States of America (Orwa et.al. 2009:2).Although, this Opuntia is found growing from the hottest deserts to the snow-capped mountains and has been part of the human diet for at least 9,000 years (Nobel 1998) still it is eaten mainly fresh and, in most countries, processing remains limited (Sáenz 2013:111).It is a valuable natural resource and is underutilized in many countries. It can use as fodder for livestock and can empower economic activities as well as it may contribute to the food security of populations in agriculturally marginalized areas (Mandragon-Jacobo and Perez-Gonzalez 2002:4). 


\section{(C) Dr. Basanta Kumar Mohanta}

Furthermore, it is also believed that in Africa this prickly pear was for the first time introduced in Cape (South Africa) over 300 years ago (FAO and ICARDA Briefing) and in North Africa in the $16^{\text {th }}$ century (Griffiths 2004, as mentioned by Salim et.al. 2009:1623). In comparison to these, the introduction of this prickly pear to Eritrea is very late. It is an exotic plant which was introduced to this country very late, by a French Catholic missionary, who planted it in few places (like Digsa, Akrur, and Hebo) of eastern part of Zoba (Zone) Debub (Fig. 01).Later, it was planted either sides of the railway lines, along the steep slopes of Arbe Rebu in order to protect soil erosion and land sliding on the railway line (Fig. 02-03). This plant has spread dramatically into many parts of the Green Belt Zone ofthe eastern escarpment of the country (Ministry of Agriculture 2002:68).The erratic and torrential rainfall patterns of Eritrea are a major reason for crop failures in this country. Because of this, the juicy beles is considered as one of the alternative crops suitable to the local environment of this country.

This prickly pear cactus fruit is locally known as 'Beles' in Eritrea and is considered as a major non-wood forest products of the country, which is available in an estimated area of $100 \mathrm{~km}^{2}$ and the potential is 24,000 tonnes per year with a current production of 4,800 tonnes per year. It is an edible fruit and the leaf is used as animal feed (Ministry of Agriculture 2002:69).The geomorphological situation of northern Ethiopia and the southern Eritrea is having similarities. Considering the case of Tigray ethnic group of northern Ethiopia (bordering Eritrea)Brutsch (1997:130) mentioned that;

"Desert conditions prevail in the east, changing to semi-desert, thorn savanna, and mountain savanna moving westward into the tropical highlands. More than $85 \%$ of the population is reported to be directly dependent on agriculture for a livelihood, but, with long periods of drought and unreliable rainfall, compounded by excessive human and livestock pressures on the land, famines are not uncommon, resulting in high human and livestock mortalities. It is in this context that the cactus pear plays an increasingly vital role as a source of food and animal feed. It is also used as a fuel, as a live fence or hedge, for soil conservation, and its fresh fruit as a limited source of household income. It has become an integral and impressive part of a strategy for food and feed security." 


\section{(C) Dr. Basanta Kumar Mohanta}

Similarly, according to Hagos (1977; as cited in Brutsch 1997:130) because of the growing pressure of human as well as livestock in one side and a decline in soil productivity, and repeated drought and famine, there is increasing dependence on cactus pear to reduce risk and guarantee crop and food security. Here, this cactus pear plays a vitalrole in their economic, as a source of food, animal feed, fuel wood, and, in some cases,as a means of additional income, thereby increasing the efficiency and economic viability ofsmall and low-income farmers. From these statements it is clear that the prickly pear cactus does have a lot of importance in the life and culture of the highlander Eritrea and Ethiopia.Although it is not a vegetable, it became an integral part of the food culture and economy of the locals of the present studied region. In this paper an attempt has been made to analyse the various usage of this prickly pear cactus in AdiKeih region of Eritrea, Africa. Primary data for the present article is collected by observation and interview from the Adi-Keih area of Zoba Debub which comes under the Central and Northern Highlands of Eritrea. This area is inhabited by the people of Saho and Tigrinya ethnic group and the main occupation of these people is pastoralism and agriculture.

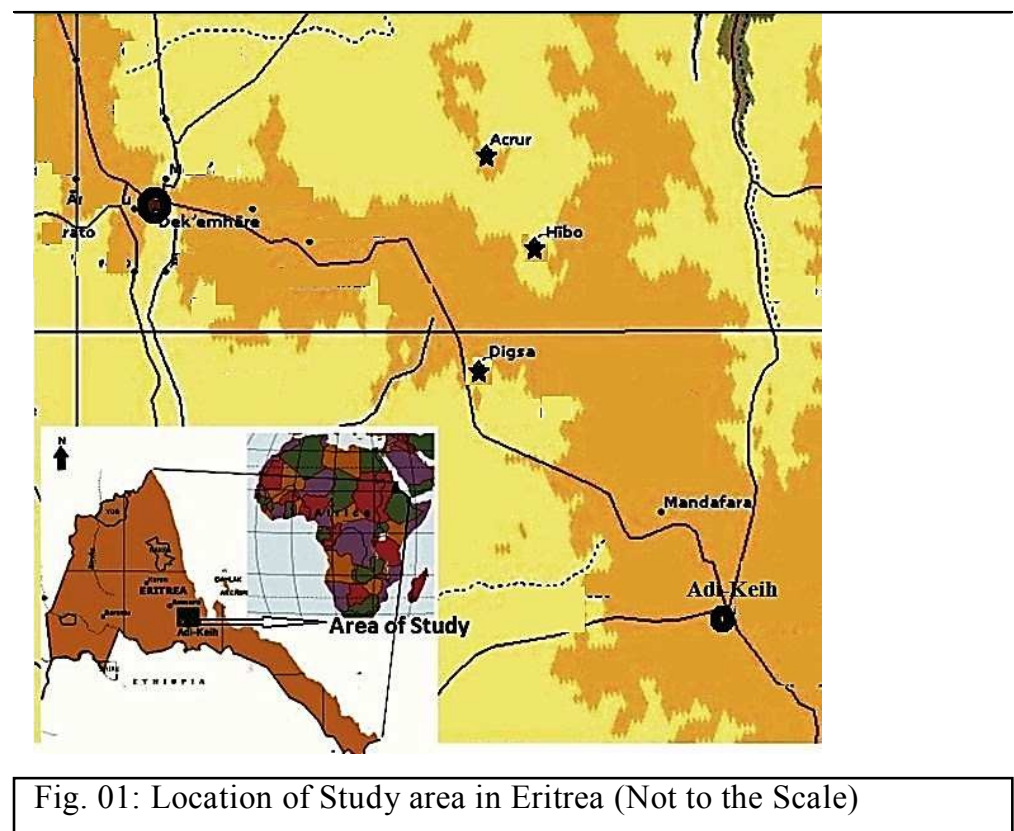


(C) Dr. Basanta Kumar Mohanta

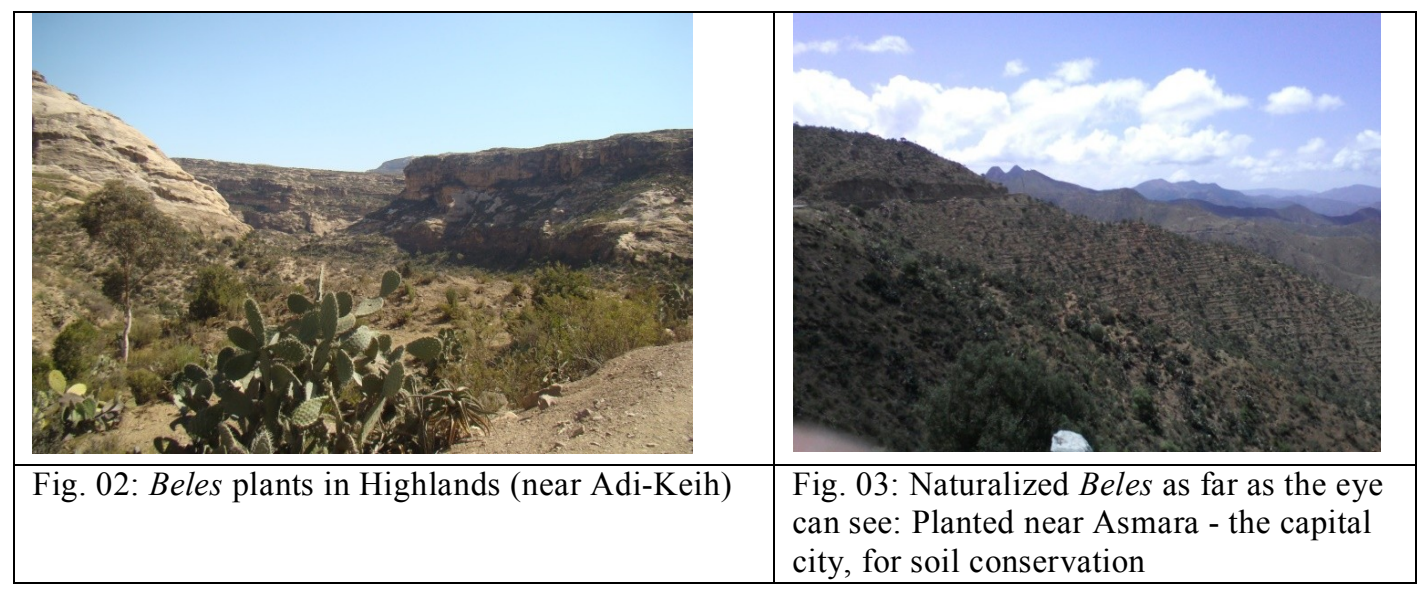

\section{Area and the People}

Eritrea $\left(12^{\circ} 22^{\prime} \mathrm{N}-18^{\circ} 02^{\prime} \mathrm{N} ; 6^{\circ} 26^{\prime} \mathrm{E}-43^{\circ} 13^{\prime} \mathrm{E}\right)$ is a recently formed, small key shaped, country, located in the North-Eastern part of Africa (popularly known as the Horn of Africa) has an area of 122,000 sq. kms. It is bounded on the east by the Red Sea, on the southeast by Djibouti, on the south and west by Ethiopia, and on the north and northwest by Sudan.The country is divided into six Zobas (administrative zones), i.e, Anseba, Debub, Debubawi, Keih Bahri, Gash Barka, Maekel and Semenawi Keih Bahri. Physiographically, this country is having diverse landforms which includes below sea level to 3,000 mts above sea level. Based on the geographical locations, the physiography of the country is divided into three major zones; (a) the Western Lowlands, (b) the Central and Northern Highlands, and (c) the Eastern Lowlands (also referred to as the Coastal Plains) (NSEO 2003:1). The country has abundant natural resources including arable land (26\% of the total area) of which only $4 \%$ is under cultivation (World Food Programme 2002; NSEO 2002:2). Since it is located in the semi-arid region of Sub-Saharan Horn of Africa, the punitive climatic conditions, human induced and natural calamities, the geographical location and low adaptive capacity render Eritrea vulnerable to the adverse effects of climate change.

Eritrea is one of the poorest countries in the world, having about US\$ 200 per capita GDP, that is far below to the average GDP (which is US\$270)for less developed countries (NSEO 2002:2; 


\section{(C) Dr. Basanta Kumar Mohanta}

UNDP 2001).Pastoralism and agriculture are the two principal sources of income of $80 \%$ of the population of the country. Since there is no population census carried out for a long time in Eritrea, no detailed record of population is available. Although the Official census data for this country is not available but based upon the population count, the Ministry of Local Government estimated the total population of the country to be about 3.2 million as of 2001 (NSEO 2002:2). Whereas, this demographic structure differs in some other reports. According to Selassie (1980:48) there are about 3.5 million people residing in this country but according to World Bank estimation, the population size of this country is about four million (World Bank 2001:596).The total population of the country is divided into nine ethnic groups based upon their languages which include the Afar, Bélin, Hidareb, Kunama, Nara, Rashaida, Saho, Tigre and Tigrinya.

\section{Nomenclature}

The history of origin of this prickly-pear is very closely associated to the Aztec culture of the early Mesoamerican civilizations. Archaeological evidence endorses that it was first cultivated by the indigenous settlers of the semi-arid regions of Mesoamerica (Pimienta 1990, as cited in Sáenz 2013:1)and after it spread to the rest of the world. As per the location, the nomenclature of this cactus varies from one language to another. In English, it is called as Indian prickly pear, Indian fig, mission prickly pear, prickly pear, Barbary fig. Similarly, in Spanish it is known as 'nopal, cardón de México, chumbera, chumbo, chumbua, higo chumbo, higo de pala, higoMéxico, higuera de pala, nopal de castilla, tuna de España, tuna española, tuna mansa, tuna, higo chimbo, tuna real, 'Tuna', 'chumbera', 'higuera de las Indias' etc; Afrikaans called it as 'boer(e) turksvy', 'doringblaar', 'grootdoringturksvy', 'kaalblaar'; Arabic 'Beles'; In French it is known as 'Indischer Feigenkaktus', 'Figuier d'Inde'; Italian 'Pero pungente', 'eico d'India'; Portuguese termed it as palma forrageira, figo da India, figo de pitoira, figueira da India, palmatoria se, espinhos, tabaido; chardon d'Inde, figue de Barbarie, figuier à raquettes, figuier d'Inde, opunce, raquette are the terms used by the French; it is known in Italian as Fichi d'India; whereas theGerman identify it as frucht des feigenkactus, Indianische feige (Orwa et.al. 2009:1; 


\section{(C) Dr. Basanta Kumar Mohanta}

Reynolds and Arias.Opuntia as forage: Introduction: 2). In Indian languages, it is known in different names, like Nagphani in Hindi, Sappattukkalli in Tamil, Nagajemudu in Telugu,Nagophenia in Odia and Hatilutur in local/tribal language of northern Odishaetc.

\section{Beles: A Scientific Description}

This Beles or prickly pear cactus (Opuntia ficus-indica) is a shrub or tree up to $05 \mathrm{~m}$ tall, forming sturdy trunk with age. Joints flattened, narrowly elliptic to ovate, varying in size, $30-60 \mathrm{~cm}$ long and 6-12 $\mathrm{cm}$ broad, attenuate below, often acute above, fairly thick, glaucous-green; areoles small to large, raised and woolly, with 3-6 radiating, unequally long, greyish white spines 03 up to $10 \mathrm{~cm}$ long, straight or occasionally slightly curved, or spineless (in older plants and some cultivars). Leaves, if developed, are minute, subulate and early deciduous. Flowers about $07 \mathrm{~cm}$ long; hypanthium broadly cylindrical, contracted below, with numerous raised areoles spirally arranged, densely wooly and filled with glochidia, occasionally also bearing small spines and minute leaves; petaloid segments yellow or orange (Fig. 04-07). Fruits ellipsoid, about $07 \mathrm{~cm}$ long, reddish, succulent, edible. Seeds are of about $05 \mathrm{~mm}$ long. There is a distinction as compaired to the spiny naturalized pears, which has invasive weeds and the cultivated, spine-less ones. The latter exits in several cultivars, e.g., O. ficus-indica forma inermis O. ficus-indica forma amyclaea and O. ficus-indica forma elongate (Orwa et.al. 2009:1).

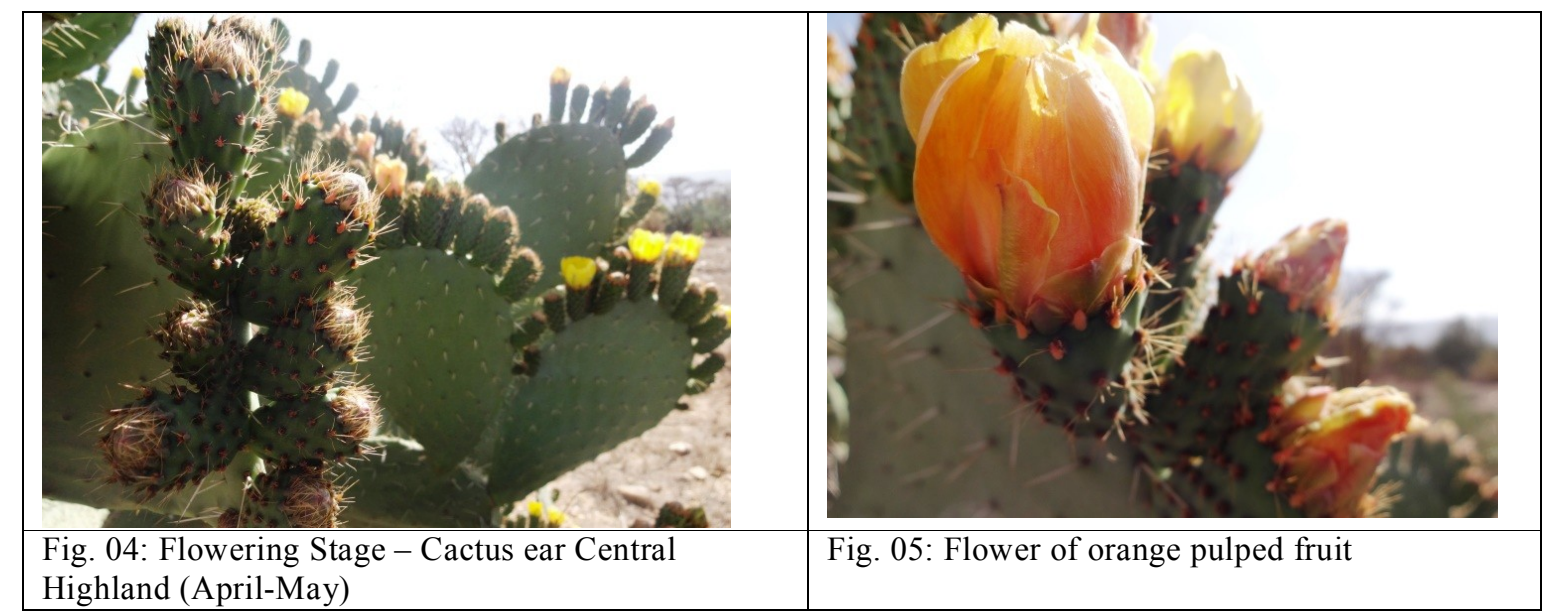



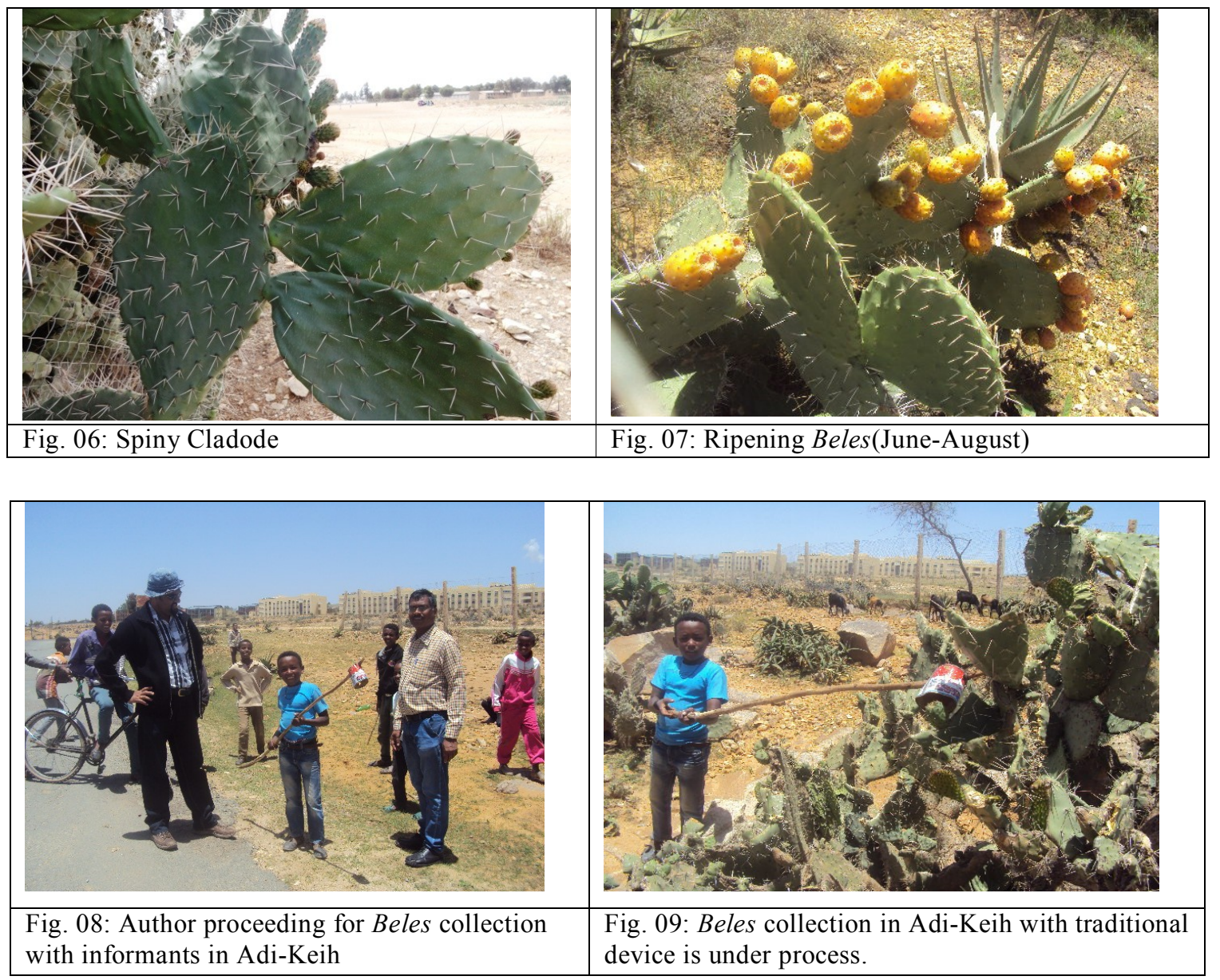

From the chemical composition of this plant it is clear that, this Beles is edible, although it needs careful peeling to remove the small spines on the outer skin before consumption. It has modest content of essential nutrients as assessed by the amount of daily value. As described in Wikipedia, the nutritional value per $100 \mathrm{~g}$ (3.5 oz) raw prickly pear consist of energy $172 \mathrm{kj}(41$ kcal); Carbohydrates $9.6 \mathrm{~g}$ (with dietary fiber $3.6 \mathrm{~g}$; fat $0.5 \mathrm{~g}$; Protein $2.5 \mathrm{~g}$; Vitamin A equiv. 25 $\mu \mathrm{g}(3 \%)$. The nutritional composition of this cactus pear fruit plays a significant role in human diet in Eritrea. It is highly nutritious and contains a unique photochemical, vitamins, and minerals profile that contributes to its many beneficial effects. This cactus has high content of 


\section{(C) Dr. Basanta Kumar Mohanta}

water and carbohydrate, but less protein contents. With such good mineral and vitamin content cactus pear provides a nutritional alternative that can increase this plants fruits and vegetable consumption and consequent contribution to a healthy diet (Table-1). The major components of the fruit pulp are water $92 \%$, carbohydrates $4.5 \%$, crude protein $1.5 \%$, ash $1.3 \%$ and crude fiber $1.1 \%(\mathrm{FAO}, 1996)$.

\begin{tabular}{|l|c|c|c|c|}
\hline \multicolumn{1}{|c|}{ Component (\%) } & Beles & Orange & Banana & Papaya \\
\hline Water & $\mathbf{8 5 . 0}$ & 87.0 & 75.7 & 88.7 \\
\hline Total carbohydras & $\mathbf{1 1 . 0}$ & 11.0 & 22.2 & 10.0 \\
\hline Crude fiber & $\mathbf{1 . 8 0}$ & 0.50 & 0.84 & 0.80 \\
\hline Lipid & $\mathbf{0 . 1 0}$ & 0.10 & 0.20 & 0.10 \\
\hline Protein & $\mathbf{0 . 5 0}$ & 0.40 & 0.70 & 0.60 \\
\hline Ash & $\mathbf{1 . 6 0}$ & 0.40 & 0.80 & 0.60 \\
\hline Calcium & $\mathbf{6 0 . 0}$ & 40.0 & 7.00 & 20.0 \\
\hline Vitamin C & $\mathbf{3 0 . 0}$ & 50.0 & 20.0 & 50.0 \\
\hline Vitamin A & $\mathbf{5 0 . 0}$ & 200.0 & 0.03 & 1100 \\
\hline \multicolumn{2}{|l|}{ Table-1. Nutritional composition of cactus fruit compared with other fruits.(AfterBarbera et.al. 1995:132). } \\
\hline
\end{tabular}

It can be observed from the above table that Beleshas almost the similar nutrient value to that of Orange, Banana, and Papaya. The caloric value of its pulp is about $50 \mathrm{k} \mathrm{Cal} / 100 \mathrm{~g}-1$ comparable to that of other fruits. It also indicates about the presence of a high level of ascorbic acid. The concentration of Vitamin-C is higher than that found in Apple, Grape and Banana. It also indicates that the cactus has high content of water and carbohydrate, but less protein contents. With such good mineral and vitamin content Belesprovides a nutritional alternative that can increase this plants fruits and vegetable consumption and consequent contribution to a healthy diet. The amount of the above nutrients in Beles varies from country to country according to their research and investigations. This is because the report of countries varies from time to time, hus change in the nutritional compositions (Barbera et.al. 1995:132).

\section{Collection, Harvesting and Storage of Beles}

In Eritrea, the traditional harvesting techniques and tools are adapted to collect Belesfrom tall plants. For this, usually, a hook made of a small used tin box (having capacity of about $500 \mathrm{gm}$ ) 


\section{(C) Dr. Basanta Kumar Mohanta}

is attached at the end of a long wooden rod and properly tied with it (Fig. 08-09). Since this Beles is considered as a wild fruit and is meant for domestic consumption or for selling in local market places, the harvesters do not take much care about its quality control. The physical damage caused on the peel and stem during harvest is one of the important factors of the perishability of this fruit. This damage leads to attack by various pathogens and result in fruit decay. The skill of the harvester determines whether this technique is injurious or extended fruits. Therefore, it suffers less harvest damage to the stem end. Due to rough handling, mechanical damage of the Beles is a common post-harvest defect. Since most of the Beles in Eritrea are spiny or thorny type, the harvesters are forced to use different manual techniques in order to clean the minute thorns from the peel of the fruit which gives pleasure for consumption.

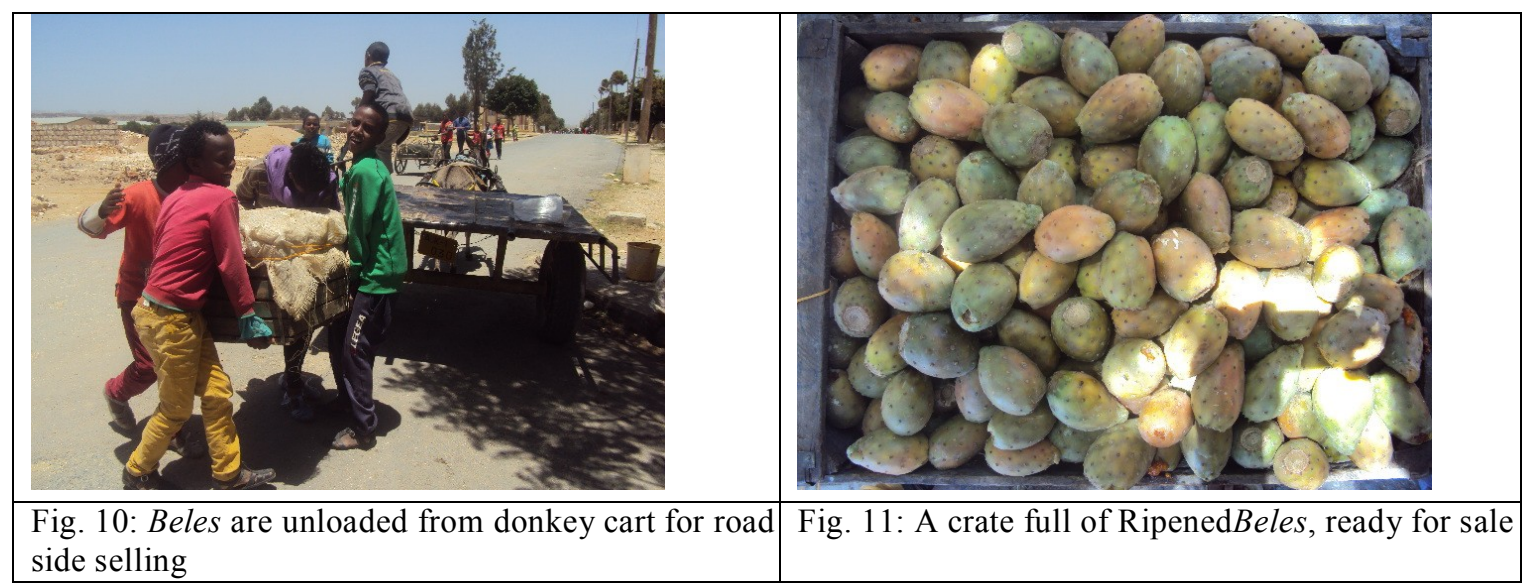

At such moments the fruit can be seriously damaged. In addition to this, mechanical damage occurs when the fruit are transferred from harvest baskets or bags to crates (Fig. 10-11). It is usually carried either by donkeys, camels, carts or trucks. These crates are overfilled and they are inappropriately stacked. Even though the quality of the cactus fruit in Eritrea is generally good, due to inadequate harvesting tools as well as poor postharvest management and handling, the fruit usually reaches to the consumer cite physically damaged on its surface and stem end. 


\section{(C) Dr. Basanta Kumar Mohanta}

Prior to the storage of the fruit in a convenient place, proper packaging system is very important to handle the fruit for marketing. Handling from the market involves cleaning the fruit, categorizing by size and colour, packing the fruit into the crates. The average weight is $25 \mathrm{~kg}$ for donkeys and $40 \mathrm{~kg}$ for truck crates. There is no such special care that has been taken in order not to have any kind of direct contact with one another inside the packed crates, which is usually done in other countries by over rapping with paper. Storage at low temperature is a very effective method for reducing water loss, because the storage life of the fruit can vary as the temperature varies. (Barbera et.al. 1995). But here in the highland, no such facilities are available. They store in natural temperature by covering with either a plastic sheet or jute bag.

\section{Importance of Beles for the Eritrean Highlanders}

People in the highlands (Halai, Tsinadegle, Segeneti, Adi-Keih) of Eritrea narrate that Beles was introduced to this country in 1824 by Bishop De Jacobis, a French missionary of Lazzaristi. The experience of more than hundred years has proven to Eritreans that this succulent plant does indeed cope with water shortage (drought) and is little affected, if at all, by the characteristic of erratic rains of Eritrea. Since, the country is economically poor and the people are regularly facing hunger and malnutrition, the utilization of natural resources like this Beles help them to have some alleviate nutritional and food security. It grows wild and is used as a living fence or as a hedge, for erosion control and for feeding ruminant livestock. The fruit is abundantly available during the late summer and early autumn (late July through September). A study by the Ministry of Agriculture in 1999 estimated that there are 4,794 tonnes of fresh Belesfruit collected during the summer months of 1999 in the areas of Arberebu and Segeniti. One-quarter of this was eaten at home' (Sáenz 2013:113). The Beles from the holy monastery of Debre Bizen is said to be particularly sweet and juicy (Source: Wikipedia). There are signs of cross breeding among the various species, which were first imported into Eritrea. However, the local community classifies the plant according to the presence or absence of thorns and as per the colour of the peel and fruit pulp. From collection to consumption of Beles, the highlanders use different traditional techniques. 


\section{(C) Dr. Basanta Kumar Mohanta}

Generally, the vegetable stems and fruits of Beles are useful for variety of purposes, such as: (a) human food (fresh fruit, paste, jam, salads and refreshing drinks); (b) animal fodder (supplementary food to cattle, sheep and goats); (c) medicinal use (ant diabetic agents); (d) for industrial products (alcohol, soap, pigments, and oil); and (e) other uses are also as a fence, soil conservation and to some extent as a landscape beauty (Sáenz 2013). In Eritrea, Beles plays an important role in the life of the highlanders. It is not only an important source of food for human being and domesticated animals but also a major source of income. On the basis of the use of this cactus plant in Eritrea, it can be categorised as (a) as a source of income, (b) as a source of animal fodder, (c) a source of human food, (d) other uses as fuel wood, fence, and soil conservation. Besides, these Belesplants are alsoproviding shelter and food for wild life in central and southern highlands as well as the eastern escarpment. More than $80 \%$ of Eritrean people fulfill the necessity of their livelihood directly from agriculture. There is an increase in population and livestock density. Pressures are imposed on the land, as a result decline in soil productivity and recurrent drought and famine occur frequently. Therefore, the reliance on Beles increases to minimize the risk and ensure crop and food security. Because of it, this Beles has an important economic role in the daily life of the Eritrean society as a means of additional income and food. A brief analysis of the various type of uses of Beles has been given below.

\section{(a) Beles as a Source of Income}

During the summer season very huge amount of cactus is supplied in different parts of Eritrea using various modes of transportation systems, like self-carrying, donkey, camel, carts and trucks. The main sources of cactus are Segeneiti, Dekemhare, Arberoubue, Durfo, Adi-Keih and Betgergish areas. The amount of cactus supply fluctuates each year depending upon the duration and distribution of rainfall in the country. The amount of cactus demand by the retailers also differs from one to other depending on their purchasing capacity and the fluctuation of daily market in their selling spots. However, majority of the retailers can purchase 1-3 crates of donkey or 1-2 crates of truck camel in each day. Retailers sell their Beles fruit either by sitting in 


\section{(C) Dr. Basanta Kumar Mohanta}

one permanent place or by moving from place to place. Each retailer has a specific place, such that a person who starts first occupies a good position.

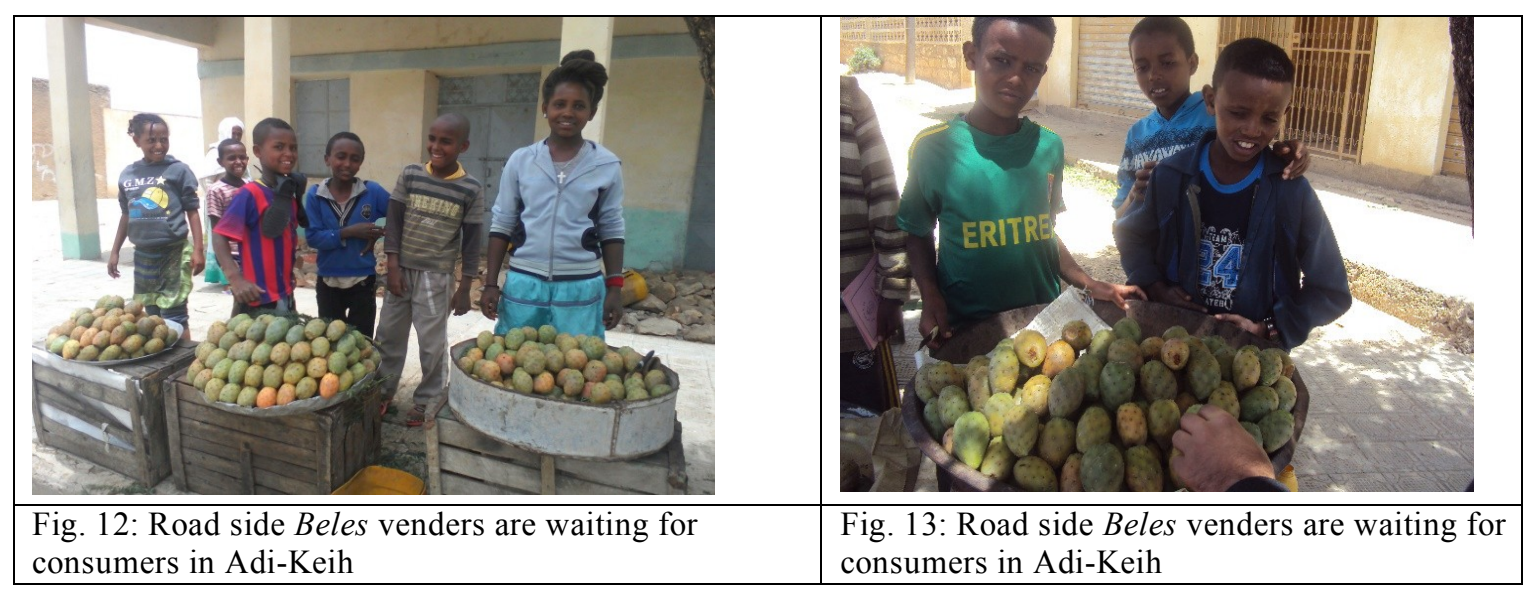

The economic importance of Beleshas remarkably increased recently. This is due to the high degree of resistance of the plant to drought and high temperature range to their adaptability. It can be grown even in fertile soil and also in arid and semiarid climatic zones. Most tropical vegetables and fruits have low productivity due to their low resistance to drought and acidity and low capacity of their adaptation to different climatic environments. The frequent busy seasonal open road side cactus pears stand lined along the streets of cities and towns throughout the country. Both adults and school children gain cash income from the seasonal market of Beles(Fig. 12-13). Especially, students whose school breaks also coincides with that of the fruiting season do have the opportunity of engaging in harvesting and marketing cactus pears during the two months of summer. This season is mainly the harvesting and selling period.

Increasing food production leads to greater opportunities of food and economic growth in the domestic and overseas market. Generating income on the other hand can also provide access to more various foods. It provides cash for use in other areas of economic activities. Beles cultivation could also be considered as one of the activities in food production process. However, people's awareness towards Beles production as a source of cash crop is limited in this country. 


\section{(C) Dr. Basanta Kumar Mohanta}

This phenomenon is due to poor handling and poor storage mechanisms. Introduction of modern cultivating system particularly individual foreign investors and cultivators could help to improve the fruit quality and quantity. This also helps to extend harvesting time. At a global level the commercial aspects of Beles involved by different private and commercial enterprises for maximum exploitation and benefit. For this, they use modern cultivation techniques, best means of transportation and sophisticated post harvesting management. It is obvious that a difference in cultivation techniques and mode of transportation influences both costs and revenues arising from the Beles market. For example, there is high commercial exploitation and utilization of cactus pear in securing their income in countries like Italy, Mexico, South Africa, Chile, Brazil, Colombia etc (Sáenz 2013). However, there is no much commercial exploitation of Beles in Eritrea due to lack of modern cultivation techniques, poor mode of transportation and limited awareness of the people towards commercial aspects of Beles. Beside this, there is minimum exploitation of Beles as insignificant cash and food by using traditional way of harvesting techniques and the commercial process of Beles fruit such as gatherers, whole sellers and retailers.

In Eritrea, Beles demand is concentrated in the second half of the year (June-September) which corresponds to the ripening and commercialization of the fruit in the most urban centers and the main source areas. Regarding the harvesting calendar of Belesin Eritrea more than $60 \%$ of ripened cactus reaches its commercial maturity in the maximum harvesting period (mid-July, and end of August), while the rest is equally spilt between the initial period (mid of June and mid of July) and the final one are in September to early October. Most of the time, the Beles is usually commercialized at the formal markets usually sold by the street vendors to the consumers in crowded places. Often the gatherers themselves retail the fruit to receive better benefit, but this is possible only in market places near the production areas. However, mostly market places are far away from the production areas.Because of this the retailers are forced to purchase the fruit from gatherers and resell it in urban streets. The supply of cactus fruit follows different marketing channels that involve different marketing agents, like, (a) gatherers to consumers, (b) gatherers to 


\section{(C) Dr. Basanta Kumar Mohanta}

retailers to consumers, and (c) gatherers to whole sellers to retailers to consumers. Every year there are more than one thousand retailers active in this business in Asmara, the capital city ofEritrea and about twenty to thirty in Adi-Keih (a sub-zone in Eritra. This shows that despite being seasonal work, the business of Beles plays a significant role in poverty alleviation and covers major expenses of living and provide children with school expenditure in the beginning of a new academic year. During the mid-period when the Beles are available in plenty, most of the retailers sell the larger size and good quality fruit at $1.0 \mathrm{Nakfa}(15 \mathrm{Nakfa}=1$ USD) and small and poor quality were sold cheaper than this accordingly. But when the supply used to decrease the price is hiked. Some retailers also sell their fruit at a lower price in the late afternoon in order to finish early. Most of the retailers sell one single cactus fruit at a price of $1.0 \mathrm{Nakfa}$. Therefore, a retailer can get a profit 240 and 100 Nakfa per day per crate of a truck and donkey respectively.

\section{(b) Beles as a Source of Animal Fodder}

The chopped Belescladodes fed with barley hay to cattle and other domesticated animals. Since the usual fruiting period of Beles is June to September, this becomes helped to the time when the highlander farmers and their animals who face different problems related to the shortage of food grain and fodder. During that crisis time this Belesfruits, the cladodes and the fruit peels help them effectively as a supernumerary crop which used to continue till the next harvest.These peels of cactus are used for animal feed for domesticated animals like cattle, horse, donkey and camels (Fig. 13, 14). Many of the retailers sold their peel at a very low price to animal breeders and cart owners. This low price of peel is due to the fact there are another options of animal feed during summer, like grass and other available green vegetation.

\section{(c) Beles as a Source of Human Food}

Eritrea is a country which has a tropical climate with desert and semi desert areas. Beles particularly suits these requirements and becomes important to the economy of arid zones for both subsistence and market oriented activity. The increased importance of Beles in arid zones is because of their ability to grow in deserts and is drought tolerant, and possess highly specialized photosynthetic mechanism that allows being more efficient than grasses. 


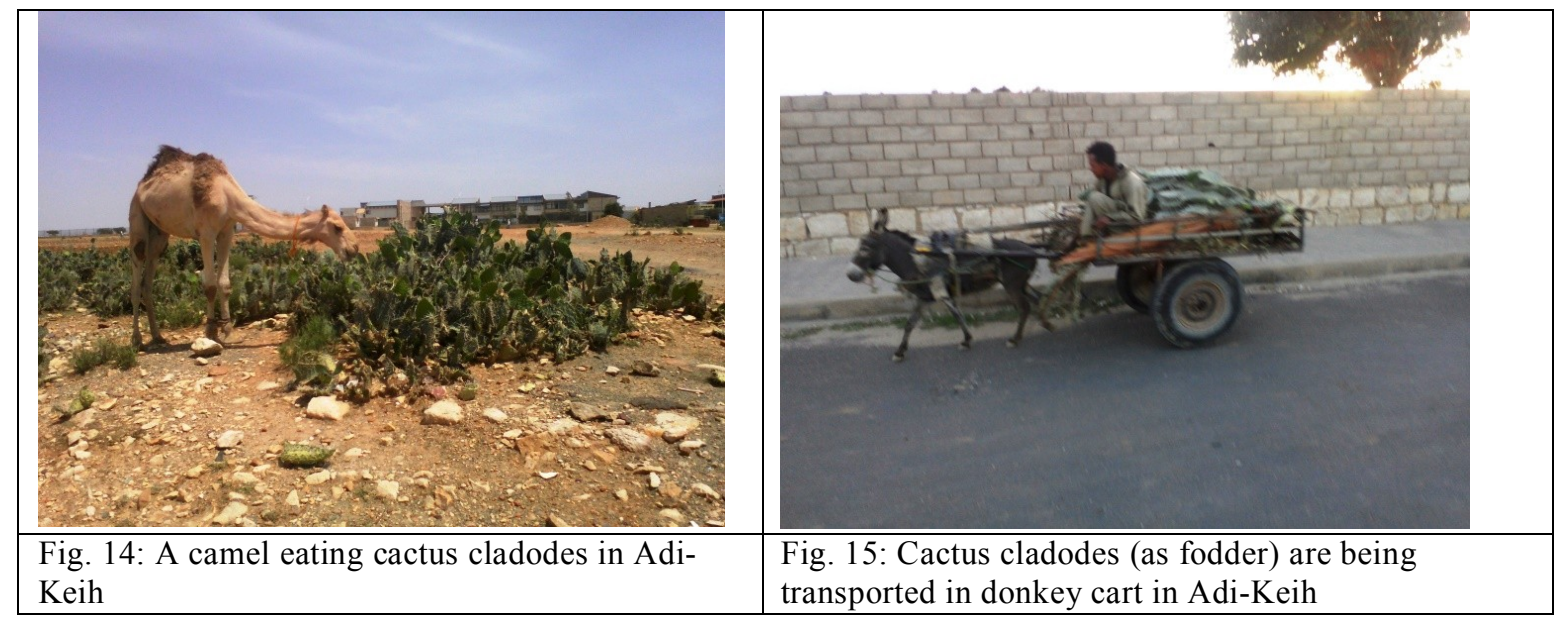

It also produces fruit forage and other useful products. Beles has many advantages over other traditional fruits and vegetables. Due to their remarkable generic variability, Beles plants show a high ecological adaptably and can therefore survive virtually in all climatic conditions. It is also used as a vegetable, fruit and flowers at one time. Despite Belesbeing accepted as a food universally, it has played a great role as a source of human food in many parts of the world.Especially in countries like Mexico, this Beles is an important part of their diet. Here, in Eritrea, in spite of the fact, it has been widely used as a valuable food source as a fruit during summer it has not yet gained much attention. However, Beles has a great potential in Eritrea serving as human food and it is found in many parts of the country. Fortunately, the fruiting season, which usually starts around June-July and extends up to the October (last year, i.e. 2016, it extended up to the mid of November), coincides with the end of dry season and the beginning of the main rainy season. This period being a low stock season for most grains, the cactus pear fruit acts as a bridge crop or as a buffer food to main farming communities until the next rain fed vegetables and crops are harvested. The fruit is also popular as seasonal food among urban dwellers of all age groups. In this country, where there is a shortage of foodsupply, it plays a great role in their food security campaign. The fruit ofBeles is very delicious whereas the peel of Beles is vicious, which needs special care during eating. Usually it is considered as a staple diet 


\section{(C) Dr. Basanta Kumar Mohanta}

in Mexico and Central America where they used to slice both ends of the Beles off and remove the fleshy skin and make long slices which is easy to eat. In Eritrea, the process of eating is slightly different. Here, after discarding both stem and other endof the Beles, the fleshy skin wrapped around it, is sliced vertically and removed from one side to get the edible part of the Beles which is directly eaten. Some people used to discard the seeds at the time of chewing. The road side vendors used to remove the fleshy cover and give the core edible part to the customer who consume it at that placeitself (Fig. 16-18). The fleshy covers are collected for domestic animals as fodder. In domestic consumption, it is used as salad or decorated in dining table for family party.
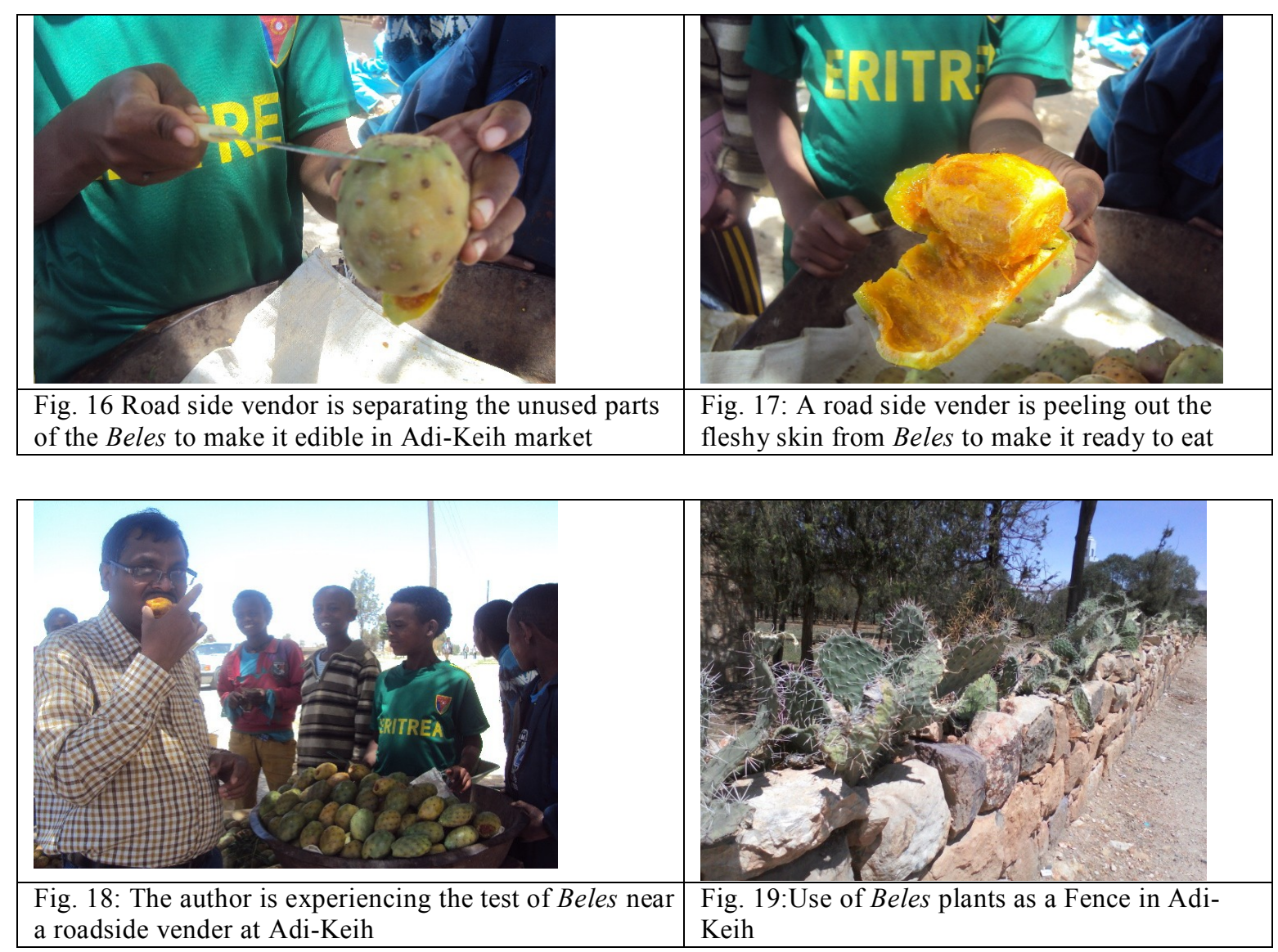
(C) Dr. Basanta Kumar Mohanta

\section{(d) Other Uses asFire Wood, Fence, Soil Conservation}

Apart from the above uses, Beles plant is used as fire wood and is also very much associated to the issues of environmental and soil conservation. In many countries,Beles is being used to prevent soil erosion and combat desertification. Since, this plant can grow in arid and semi-arid areas it can survive and spread under conditions of scarce and erratic rainfall and high temperatures and can play an important role in the protection of local fauna. Besides, this plant has a limitless capacity for adaptation, growing in severely degraded soils which are scarce for other crops and are ideal for responding to global environmental changes (Mandragon-Jacoboand Perez-Gonzalez 2002:4).In case of Eritrea, even though it is a naturalized crop,introduced about 135 years ago, the plant is successfully working as an important ecological alternative for arid and semi-arid areas. During construction of railway line, it was widely planted alongside the rail track to conserve the soil erosion. After that it spread very fast in the highland. In Adi-Keih area it is found in the hill slope of the valley area as well as on the embankments of the agricultural fields. Besides it is also used as fire wood and fence of houses and agricultural fields (Fig. 19).

\section{Conclusion}

Even if,Beles has been introducedto human life long beforeand is subsequently domesticated, it is comparatively new to the people of the highland Eritrea which hadfamiliarized to them only about 150 years back. The different parts of Beles have its own significance and are used for different purposes in different corner of the globe. From the chemical and nutritional compositions, it is clear that it is a very good and healthy food not only for the animals but also for the human being. It could be used as a raw food or processed food.Apart from the regular use, now-a-days in many countries of the world, the cladode, flower and fruit of Beles are processed and prepared a variety of products as food supplement, liquor, medicines, colourants, hydrocolloids (mucilage), cosmetic, bioenergy, biogas, fertilizers etc.As food supplement, a number of natural products, like capsules and tabletsof cladode powders, powders for mixing intodrinks and others formulated with a mix of plantfibers are used as traditional medicines. For 


\section{(C) Dr. Basanta Kumar Mohanta}

example, in the United States of America, an extensive variety of Belesbased foods are prepared. The manufacturers advertise in internet and other medias about the numerous methods of eating and enjoying Beles fruit and cladodes and its products as jams, candies, medicines, food supplements, drinks etc.Mexico processesBelesin saltwater and exports it to Europe, Canada, the United States and the Pacific Basin countries. The cosmetic products from Beles plant and fruit are very complex and extremelymodest. Varieties of products like, soaps,shampoos and various types of creams, lotions andface masks are made in Mexico. Besides these traditional and modern uses, there are also probability fora number of other novel uses as adhesives for corrosion prevention and as an additivefor paints and adobe in the construction sector; use for soil improvement in agriculture. In Chile and Mexico, these are used asapaste for making calcium hydroxideand for purifying water. Besides, this Beles offers an alternative source for making natural colour (Sáenz, Carmen. 2013:111-123). Similarly, in rural areas of Manipur (India), these Beles are being used to lubricate (like grease) the bullock cart and wooden toys (personal communication with Dr. Berkha Chettry of District Senapati).

But in case of Eritrea, this Beles is the known as the cheapest summer fruit and is mainly used as a raw fruit in summer and animal fodder.Even the highlanders do not have any idea about the use of Beles and cladode as vegetable and cooked food. They are completely unaware about the modern use of Beles in various purposes as it is seen in American and European countries. Here, it iscould be a great potential for the low income families both as source of income and food. Therefore, it has become an integral part of the culture and economy of Eritrean highlanders and part of the escarpment.Since, Belesplant isable to adapt in different climatic conditions, it grows very fast in many parts of Eritrea. Thus,the plant gaining new respect as a potential food source in an area which have inconsistent rainfall, environmental degradation, poor quality soils and other problems. Economically, this plant plays a significant role as household income and poverty alleviation in both the production and consumption areas. The fruit is a common delicacy which is selling in the selling spots along the road sides, near the retailer's residence, bus stop and bus stations.Majority of the retailers are students, since the business is held in 


\section{(C) Dr. Basanta Kumar Mohanta}

summer, and the retailer'sget from the cactus business aminimum of 5,000 Nakfa up to 18,000 Nakfa as income through the whole summer. Although Beles has a great potential as a source of human food it has not yet gain any attention as a basic food. Beles is only consumed as a raw fresh fruit. Huge amounts of fruit are consumed by the local people during summer.

\section{Acknowledgements}

The author is thankful to his former student Kaled Abduelalim Hassen for insisting to prepare an article on this topic and for hisassistance at different stages in preparation of the article.

\section{References}

Abay, F. 1997. Tapping Farmer's Knowledge of Cactus. Tigray, Ethiopia.

Anaya-Pérez, Marco Antonio. 2002. History of the Use of Opuntia as Forage in Mexico. In Mandragon-Jacobo, Candelario and Salvador Perez-Gonzalez (eds.). Cactus (Opuntia spp.) as Forage. Rome: FAO International Technical Cooperation Network on Cactus Pear. Pp. 5-12

Barbera, G., P. Inglese, and E. Pimienta-Barrios (eds.). 1995. Agro-Ecology, Cultivation and Uses of Cactus Pear. FAO Plant Production and Protection Paper No. 132, Rome.

Basil, F. 2001. Economic aspect of Cactus Production and Market. Italy: University of Catania.

Brutsch, M.O. 1997. The Beles or Cactus Pear (Opuntia ficus-indica) in Tigray, Ethiopia. J. PACD. 130-141.

FAO and ICARDA. Cactus Pear in South Africa: History, Challenges, and Potential. Briefing of Cactusnet: Promoting the Social and Ecological Benefits of Cactus Production. www.icarda.org / www.cactusnet.org (accessed on 16/2/2016).

Govt. of Eritrea. Ministry of Agriculture. 2002. The National Action Programme for Eritrea to Combat Desetification and Mitigate the Effects of Drought (NAP). Asmara: Ministry of Agriculture. 


\section{(C) Dr. Basanta Kumar Mohanta}

Govt.of Queensland. 2007. Fact Sheet, Biosecurity Queensland. Invasive Plants and Animals: The Prickly Pear Story. The State of Queensland. (Department of Primary Industries and Fisheries). $<$ www.dpi.qld.gov.au $>$

Griffiths, P. 2004. The Origins of an Important Cactus Crops, Opuntia ficus-indica (Cactaceae): New Molecular Evidence. Am. J. Bot. 91:1915-1921.

Hagos, F. 1997. The role of 'Beles' in household food security under different farming systems of Tigray. Paper presented at the International Workshop on 'Opuntia in Ethiopia: state of knowledge in Opuntia research'. Mekelle University College, Tigray, Ethiopia, 22 to 27. February, 1997.

Mandragon-Jacobo, Candelario and Salvador Perez-Gonzalez (eds.). 2002. Cactus (Opuntia spp.) as Forage. Rome: FAO International Technical Cooperation Network on Cactus Pear.

Ministry of Agriculture. 2001. Document of Rainfall in Eritrea.Asmara.

NSEO (National Statistics and Evaluation Office) [Eritrea]. 2003. Eritrea Demographic and Health Survey 2002. Calverton, Maryland, USA: National Statistics and Evaluation Office and ORC Macro.

Orwa, C., A. Mutua, R. Kindt, R. Jamnadass, and S. Anthony. 2009. Opuntia ficus-indica. Agroforestree Database:a tree reference and selection guide version 4.0 (http://www.worldagroforestry.org/sites/treedbs/treedatabases.asp). Pp. 1-5.

Sáenz, Carmen. 2013. Chapter-1: Opuntias as a natural resource. In FAO Agro-Industrial Utilization of Cactus pear. Rome; Food and Agriculture Organization of the United Nations. Pp.15 .

Sáenz, Carmen. 2013. Chapter-9: Case studies on agro-industrial utilization of Opuntia species in several countries. In Sáenz, Carmen., Horst Berger, Armida Rodríguez-Félix, Ljubica Galletti, 


\section{(C) Dr. Basanta Kumar Mohanta}

Joel Corrales García, Elena Sepúlveda, María Teresa Varnero, Víctor García de Cortázar, Roberto Cuevas García, Enrique Arias, Candelario Mondragón, Inocencio Higuera and Cadmo Rosell. Agro-Industrial Utilization of Cactus pear. Rome; Food and Agriculture Organization of the United Nations. Pp.113-124.

Salim, Nebbache., Chibani Abdelwaheb, Chadli Rabah and Bouznad Ahcene. 2009. Chemical composition of Opuntia ficus-indica (L.) fruit. African Journal of Biotechnology 8 (8):1623-162. Selassie, B.H. 1980. Conflict and Intervention in the Horn of Africa. New York; Monthly Review Press.

World Bank. 2001. Eritrea: Options and Strategies for Growth. Washington D.C.; Hoopla. 